\title{
MicroRNAs, major players in B cells homeostasis and function
}

\section{Richard Danger 1,2,3, Faouzi Braza ${ }^{2,3}$, Magali Giral ${ }^{2,3,4}$, Jean-Paul Soulillou ${ }^{2,3,4}$ and Sophie Brouard ${ }^{2,3,4}$ *}

1 Institute of Liver Studies, Medical Research Council Centre for Transplantation, King's College Hospital, King's College London, London, UK

2 Institut National de la Santé et de la Recherche Médicale, U1064, Institut de Transplantation Urologie Néphrologie, Nantes, France

${ }^{3}$ Faculté de Médecine, Université de Nantes, Nantes, France

${ }^{4}$ Centre Hospitalier Universitaire, Hôtel Dieu, Nantes, France

Edited by:

Frans Claas, Leiden University

Medical Center, Netherlands

Reviewed by:

Philippe Saas, Etablissement Français du Sang BFC, France

Michael Eikmans, Leiden University

Medical Center, Netherlands

*Correspondence:

Sophie Brouard, Institut National de la

Santé et de la Recherche Médicale,

U1064, 30 Bd Jean Monnet, 44093

Nantes Cedex 93, France

e-mail: sophie.brouard@

univ-nantes.fr
As a main actor in humoral immunity, B cells participate in various antibody-related disorders. However, a deeper understanding of B-cell differentiation and function is needed in order to decipher their immune-modulatory roles, notably with the recent highlighting of regulatory $B$ cells. microRNAs (miRNAs), key factors in various biological and pathological processes, have been shown to be essential for B-cell homeostasis, and therefore understanding their participation in B-cell biology could help identify biomarkers and contribute toward curing B-cell-related immune disorders. This review aims to report studies casting light on the roles played by miRNAs in B-cell lineage and function and B-cell-related immune pathologies.

Keywords: B cell, immunology, immune disorder, microRNA, gene-expression regulation

\section{INTRODUCTION}

MicroRNAs (miRNAs) are the most studied class of non-coding RNAs and their gene-expression regulating role is key in various biological and pathological processes. MiRNAs play a role in immune processes such as the development of immune cells, inflammation, and tolerance $(1,2)$. Evidence that miRNAs are needed for B-cell development is given by mice where B-cellspecific deletion of the endoribonuclease Dicer results in a lack of B cells (3). Furthermore, miRNAs finely tune the differentiation and activation programs of B cells, thus influencing their function. $B$ cells are also central mediators in humoral immunity and play an important role in transplantation, autoimmunity, and reaction to infectious diseases. Consequently, it is important to understand in what circumstances miRNAs can influence B-cell function, and therefore immuno-pathology. In the present review, we describe recent studies shedding light on the roles played by miRNAs in Bcell biology and B-cell-related immune pathologies (major miRNA roles in B cells are reported in Table $\mathbf{1}$ and Figure $\mathbf{1}$ ).

\section{MicroRNA CHARACTERISTICS \\ BIOGENESIS}

Discovered in Caenorhabditis elegans in 1993 by Ambros and Ruvkun's teams, miRNAs are endogenous small (19-23 nucleotides in length) non-coding RNAs that perform post transcriptional regulation by targeting messenger RNAs (mRNAs) for degradation or translational inhibition $(30,31)$. Since their first description, miRNAs have been extensively studied. The 20th release (June 2013) of the official miRNA registry, miRbase, contains 2, 578 and 1, 908 mature miRNAs for human and mouse, respectively (32). MiRNA biogenesis has been reported in detail (33). The canonical miRNA biogenesis involves the transcription of long primary transcripts (pri-miRNA) by the RNA polymerase
II which allows transcription factor regulation (34). This primiRNA is processed by the microprocessor complex, including the endoribonucleases Drosha/Di George syndrome critical region protein 8 (DGCR8). The resulting precursor miRNA (pre-miRNA) is transported into the cytoplasm where it is processed and cleaved by the Dicer RNase III. This process leads to the formation of a short double-stranded RNA containing the miRNA and its complementary sequence. Finally, the mature miRNA is unwrapped and packed in the RNA-induced silencing complex (RISC). This complex is composed of several proteins including the Argonaute proteins (AGO) and allows a stable conservation of the miRNA. This RISC complex guides the miRNA to the target mRNA containing miRNA Recognition Elements (MRE) (35).

\section{MECHANISMS OF ACTION}

The most widely accepted model for miRNA targeting is based on the seed region, a 6 nucleotide region in the $5^{\prime}$ end of the miRNA, where miRNA/mRNA matching is perfect, whereas an uncomplimentary region, or "bulge" sequence, is present between the miRNA/mRNA hybrid (36). Due to this short recognition sequence, miRNAs are predicted to target hundreds to thousands of genes. This is confirmed in different reports where deletion or over-expression of miRNAs regulate the expression of numerous genes and proteins $(37,38)$. Consequently, a lot of predictive bioinformatic tools have been developed to identify potential direct miRNA targets [reviewed in Ref. (39)]. However, even the most accurate software gives a high rate of false positives and false negatives and predictions have to be experimentally validated.

The exact mechanisms by which miRNAs repress geneexpression still remain unknown. Recent experiments suggest that miRNAs act as protein transcriptional repressors, preventing ribosome association with mRNAs, leading to mRNA destabilization 
Table 1 | Major miRNAs playing a role in B cells.

\begin{tabular}{|c|c|c|c|}
\hline miRNA & Targets & Biological effects & Associated disorders \\
\hline miR-17-92 & $\operatorname{Bim}(3,4)$ & Participate in B-cell proliferation and cell-death & \\
\hline Cluster & Pten (4) & control $(3,4)$ & \\
\hline $\operatorname{miR}-24$ & $\begin{array}{l}\text { Bim and Caspase } 9 \\
\text { (5) }\end{array}$ & $\begin{array}{l}\text { Inhibit B-cell development, under the control of } \\
\text { PU.1 }(5,6)\end{array}$ & \\
\hline miR-29a & $\begin{array}{l}\text { TCL1, MCL 10, and } \\
\text { CDK6 (7) }\end{array}$ & & $\begin{array}{l}\text { Up-regulated in indolent B-cell chronic lymphocytic leukemia } \\
\text { (CLL) compared to normal B cells (8). }\end{array}$ \\
\hline miR-34a & Foxp1 (9) & $\begin{array}{l}\text { Induces block of B-cell development whereas its } \\
\text { deletion induces high number of mature B cells (9) }\end{array}$ & \\
\hline miR-146a & $\begin{array}{l}\text { Irak1 and Traf6 (10) } \\
\text { Fas (11). }\end{array}$ & $\begin{array}{l}\text { Participate in B-cell development, over-expression } \\
\text { causes spontaneous autoimmune disorders in } \\
\text { mice }(10,11)\end{array}$ & $\begin{array}{l}\text { Over-expressed in patients suffering from rheumatoid } \\
\text { arthritis and psoriasis (12-14) } \\
\text { Over-expressed in kidney biopsy and urine from patients } \\
\text { with IgA nephropathy (15) } \\
\text { Induced by EBV and inhibits the expression of interferon } \\
\text { related genes (16) }\end{array}$ \\
\hline $\operatorname{miR}-150$ & $c-M y b(17)$ & $\begin{array}{l}\text { Its over-expression in B-cell progenitors results in a } \\
\text { partial block of B-cell development and a reduction } \\
\text { in B1-cell numbers (17). }\end{array}$ & Under-expressed in peripheral B cells from SLE patients (18) \\
\hline miR-155 & $\begin{array}{l}\text { Pu.1 (Sfpi1 gene) (19) } \\
\text { Shp1 (21) } \\
\text { Aid }(20,22)\end{array}$ & $\begin{array}{l}\text { Reduced generation of high-affinity antibodies } \\
\text { against a T-cell-dependent antigen }(19,20)\end{array}$ & $\begin{array}{l}\text { Over-expressed in peripheral B cells from SLE patients (18) } \\
\text { Is induced by EBV, through LMP1 and: } \\
\text {-targets BMP signaling cascade suggesting an inhibition of } \\
\text { the antitumor effects of BMP signaling (23) } \\
\text {-contributes to the resistance toward Rituximab in inducing } \\
\text { cell survival signal (24) }\end{array}$ \\
\hline $\operatorname{miR}-181 a$ & $\operatorname{Bim}(25)$ & $\begin{array}{l}\text { Its over-expression inhibits the pro-apoptotic } \\
\text { protein BIM (25) and increases number of } \\
\text { B-lineage cells (26) }\end{array}$ & \\
\hline $\operatorname{miR}-181 b$ & Aid (27) & Impairs the class-switch recombination (27) & \\
\hline $\operatorname{miR}-210$ & & $\begin{array}{l}\text { Control of immunoglobin class-switch and under } \\
\text { the control of Oct-2 (28) }\end{array}$ & \\
\hline $\operatorname{miR}-221$ & & $\begin{array}{l}\text { Implicated in the retention of early B-lineage cells } \\
\text { in bone marrow and under the control of PAX5 (29). }\end{array}$ & \\
\hline
\end{tabular}

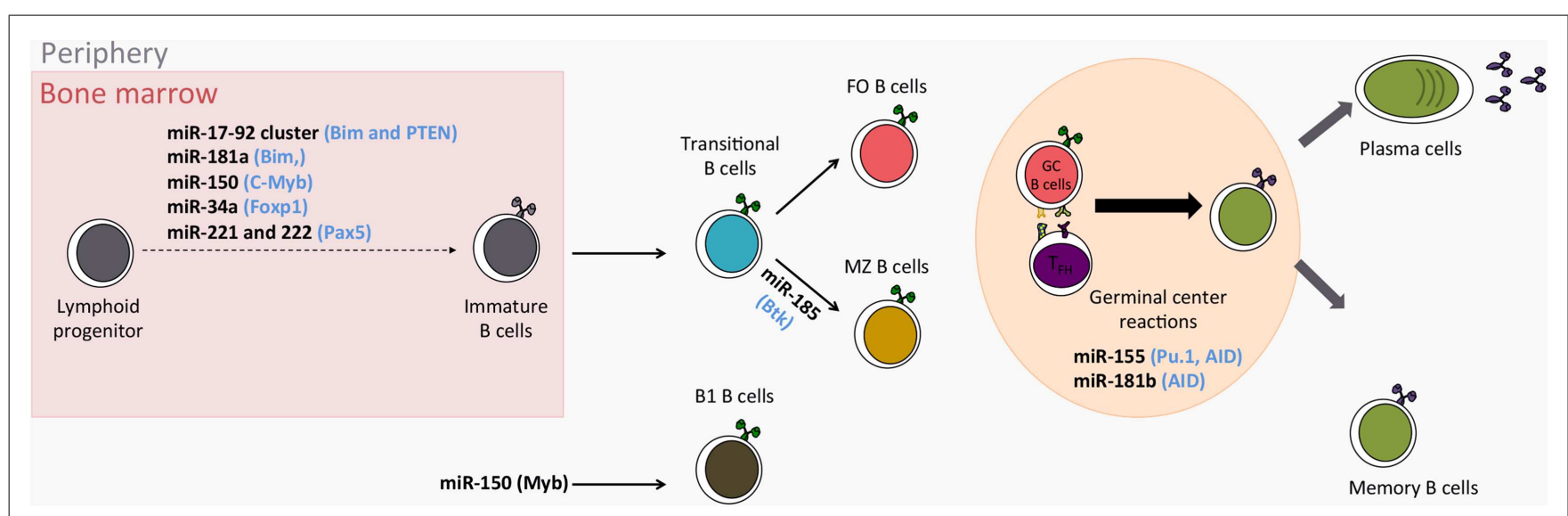

FIGURE 1 | Role of miRNAs in the development of B cells. (in Blue: miRNA targets; FO Follicular B cells; MZ Marginal zone B cells). 
and degradation (40-42). This would explain the absence of the rapid diminution of mRNA levels after miRNA induction. This would further mean that miRNAs, not requiring translation, could be active in inhibiting mRNA translation more quickly than transcription factors.

Another important property of miRNAs is that they have distinct functions in different cell types, the transcript levels differing depending on the cell, and number of mRNA containing MRE also differing. This is the case for miR-155, which represses the expression of the factor transcription c-MAF and the IFN $\gamma$ receptor 1 (IFNGR1) in activated naïve CD4 positive cells, whereas it represses the expression of the PU.1 transcription factor and the phosphatidyl inositol 5'-phosphatase SHIP1 in B-lymphocytes $[(21,43,44)$; reviewed in Ref. (45)]. Few miRNAs are cell-specific. Some lymphoid miRNAs have been identified, such as miR-150, that have been shown to be expressed in B cells and also in $\mathrm{T}$ and NK cells (46). Furthermore, miRNAs have been found expressed in various body fluids including plasma, sera, urine, saliva $(47,48)$, and their resistance to degradation, either by enzymatic (RNases) or physic (freezing/defreezing) processes make them good biomarkers.

Finally, while the large number of miRNA targets, their possible rapid intervention, and their multifactorial function explain why miRNAs are important in cell biology, the exact mechanisms of miRNA are complex and as yet undiscovered. MiRNAs can directly induce gene-expression $(49,50)$ despite being mainly described as gene-expression repressors. They can also act in the $5^{\prime}$ untranslated region (UTR), and not only in the $3^{\prime}$ UTR (51). Finally miRNAs can themselves be regulated by long non-coding RNA (52).

\section{miRNAs AND B-CELL LINEAGE}

\section{SPECIFIC miRNAs HIGHLIGHTED IN B-CELL LINEAGE}

Knock-out (KO) experiments have shown that miRNAs are involved in, and even indispensable to, normal hematopoiesis (3, 53) (Figure 1). Indeed, reconstitution of irradiated mice with Ago2-deleted bone marrow cells, which induces a reduction in miRNA levels, impairs generation of pre-B cells and subsequently peripheral B cells (53). Specifically in B cells, the Dicer ablation at an early stage blocks cells at the pro-B to pre-B-cell transition (3) whereas the Dicer ablation at a later stage, in antigen-activated $B$ cells, results in a severe impairment of antibody response with prevention of germinal center (GC) B-cell, long-lived plasma cell, and memory B-cell formation (54). Analysis of up-regulated genes in blocked pro-B cells highlights gene-bearing seed motifs for miRNAs such as miR-142-3p and the miR-17-92 cluster (including miR-17, $-19 a,-19 b,-20 a$, and -92), suggesting that at least these miRNAs are important for B-cell development (3). Among genes targeted by miRNAs from the miR-17-92 cluster, the authors showed that Bim (BCL2-like 11), a pro-apoptotic gene, is increased in Dicer $\mathrm{KO}$ mice and could be responsible, at least in part, for the massive apoptosis observed at the pre-B stage. In contrast, the over-expression of this miR-17-92 cluster in transgenic mice results in lymphoproliferative and autoimmune phenotypes due to a reduced PTEN (phosphatase and tensin homolog) and BIM protein expression (4). Altogether, these data suggest that the miR-17-92 cluster has a role in the proliferation control of B cells.
Similarly, the over-expression of miR-181a in hematopoietic stem cells induces an increase in the number of B-lineage cells in both tissue-culture and adult mice after re-implantation in bone marrow (26). A deep-sequencing experiment confirms the preferential expression of the miR-181 family in early and transitional B-cell stages (55). Furthermore, the inhibition of the pro-apoptotic gene BIM by miR-181a, reducing B-cell apoptosis, could explain the observed increased number of B cells when miR-181a is overexpressed (25). This sequencing study also confirms the expression of miRNAs related to B-cell differentiation, such as miR-146a, miR-150, miR-155, and miR-34a. MiR-150 is indispensable for Bcell development as it controls, in a dose-dependent manner, the expression of $c-M y b$ ( $\mathrm{v}$-myb avian myeloblastosis viral oncogene homolog, officially called $M y b$ ), coding for a transcription factor important in multiple steps of lymphocyte development and notably the generation of $\mathrm{B} 1$ cells, considered as innate immune cells producing immunoglobulin $\mathrm{M}$ and $\mathrm{A}$ (IgM and IgA) (17). The ectopic expression of miR-150 in B-cell progenitors results in a partial blockade of B-cell development and a reduction in B1-cell numbers whereas splenic B1 cells are four-times as numerous in miR-150 KO mice (17). Interestingly, in mice with miR-150 ectopic expression, no obvious adverse physiological effect is observed in non-hematopoietic lineage cells, demonstrating that miRNAs display their functions with cell-specificity. Similarly to miR-150, the constitutive expression of miR-34a results in a partial blockade of B-cell development, whereas its deletion induces high number of mature B cells (9). Indeed, miR-34a constitutive expression inhibits the transition of pro-B cells into pre-B cells by targeting the gene coding the transcription factor Foxp1 (Forkhead box P1). Spierings et al. described high levels of expression of miR-146a in $\mathrm{B} 1$ lineage and in to a lesser extent in marginal zone (MZ) $\mathrm{B}$ cells (55). Considering that this miRNA has been described as playing a role in a negative feedback loop on NF-kB activity by down-regulating IL-1 receptor associated kinase 1 (Irakl) and TNF receptor-associated factor 6 (Traf6) upon lipopolysaccharide stimulation in monocyte, miR-146a could be implicated in B1-cell development. The possibility of this role is reinforced by the fact that miR-146a controls Irak1 and Traf6 in splenic B cells (10) and furthermore by the association of increased miR-146a expression in $c-M y c$ related lymphoma models (56) and in splenic MZ lymphoma (57). Thus, it is clear that miRNAs play key roles in B-cell development.

As for other RNAs, the expression of miRNAs is under the control of transcription factors, which are definitely involved in B-cell development. Starting from the fact that PAX5 (paired box 5) participate in B-cell fate, Knoll et al. have shown the down-regulation of miR-221 and miR-222 during B-lymphocyte development, and the involvement of miR-221 in the retention of early B-lineage cells in bone marrow (29). A similar procedure has been shown with the transcription factor PU.1 \{encoded by the Sfpil gene [SPI1 spleen focus forming virus (SFFV) proviral integration oncogene]\}, because high ectopic expression of Pu.1 in multipotent progenitors promotes myeloid cell development at the expense of B-cell development (6). Using a Pu. $1^{-/-}$myeloblast cell line and model of bone marrow transplantation, the authors identified miR-24 as a transcriptional target of PU.1 able to inhibit B-cell development in vivo as well as in vitro (6). In contrast, the 
same group report that miR-24 enhances cell survival in both the myeloid and pre-B-cell lines, inhibiting pro-apoptotic molecules such as BIM and Caspase 9 (5). It remains unclear why this miRNA inhibits B lymphopoiesis or enhances lymphocyte survival but is likely due to a change in the cellular environment.

Regarding the other roles of miRNAs in B cells, it is clear that they partly control proliferation and apoptosis in B cells and numerous miRNAs have been highlighted in lymphoma. $\mathrm{B}$ lymphoma-related miRNAs were reviewed recently (58). Their study highlighted the role of miRNAs in normal B cells. For example, miR-155, which was initially described within the non-coding $\mathrm{B}$-cell integration cluster $(B I C)$ gene, is over-expressed in various lymphoma, and has also been shown to be a major miRNA involved in B-cell maturation. This is also the case for miR-29a, highly expressed in B cells and up-regulated in indolent B-cell chronic lymphocytic leukemia (CLL) compared to normal B cells (8). Its B-cell-specific over-expression induces a CLL-like disease in mice with an expanded $\mathrm{CD} 5^{+} \mathrm{CD} 19^{+} \mathrm{B}$-cell population suggesting that miR-29a acts as an oncomiR (8). However, this miRNA is expressed less in aggressive CLL compared to indolent CLL, and it is speculated that a reduction of control of miR-29a targets, including several oncogenes such as T-cell leukemia/lymphoma $1 \mathrm{~A}$ (TCL1), myeloid cell leukemia sequence 1 (MCL10) and cyclindependent kinase 6 (CDK6) participate to the aggressive CLL phenotype (7). Thus, miR-29a could act either as an oncogene or a tumor suppressor, demonstrating that miRNAs can play different roles depending on the cellular context. Finally, the role of miR-29a in normal B cells has not yet been described, but considering the enrichment of B-cell signaling pathways among its targets, it is also likely to have an important function in normal $\mathrm{B}$ cells [reviewed in Ref. (59)].

\section{ENRICHED miRNAs IN B-CELL LINEAGE}

Overall, most miRNAs are ubiquitously expressed, only some of them being preferentially expressed, in restricted cell types (60, $61)$; this is the case for miR-122 in liver and miR-1 in muscle. Global profiling studies focusing on hematopoietic cell lineage and particularly in B cells also foreground enriched miRNAs such as miR-16, miR-30c, miR-34a, miR-142-3 and-5p, miR-150, miR155 , miR-181, and miR-223 (46, 55, 62-65). These profiling studies are very useful tools in a first attempt to appreciate the role of a particular miRNA in conjunction with cells or tissues expressing this miRNA. This is the case for the deep-sequencing study by Spierings et al. which shows the expression of 232 known miRNAs in 10 developmental stages (55). Altogether, these studies demonstrate that miRNAs with distinct expression in B cells have to be investigated for the complete understanding of B-cell biology.

\section{IMPLICATION OF mIRNAs IN PERIPHERAL B-CELL DEVELOPMENT}

\section{ROLES OF miRNAS IN FO MZ FATE DECISION}

Primary antibody diversification takes places during B-cell differentiation in the bone marrow through somatic DNA rearrangement of Ig by $\mathrm{V}(\mathrm{D}) \mathrm{J}$ recombination. This process leads to a high diversity of $\mathrm{B}$-cell antigen receptors that can recognize selfantigens and potentially induce autoimmunity. Control of B-cell auto-reactivity is guaranteed by intrinsic tolerance mechanisms
$(66,67)$. Two checkpoints ensure B-cell tolerance in bone marrow and the periphery, where strongly self-reactive $B$ cells might undergo receptor editing or clonal deletion $(66,67)$. In mice, peripheral immature $\operatorname{IgM}^{+} \mathrm{B}$ cells start to express IgD and terminate their differentiation into follicular (FO) or $\mathrm{MZ} \mathrm{B}$ cells $(11,68)$. FO B cells are currently associated with a T dependentresponse whereas MZ B cells, located in the spleen marginal sinus, can mount independent humoral responses. The differentiation of immature B cells into FO or MZ B cells depends on BCR intensity signals and cleavage of Notch2. For their differentiation MZ B cells need weak BCR signals, allowing the activation of Notch2 pathways, whereas FO B cells are generated after strong, tonic BCR interactions associated with BAFF survival signals (11). MiRNA are involved in the FO vs. MZ fate decision (69). Mice with conditional $\mathrm{KO}$ of Dicer in B cells exhibit a total switch of their B-cell subsets, with a higher proportion of immature and MZ B cells and a strong alteration of the FO B cells (69). This alteration is specific to Dicer deletion and not due to any compensatory homeostatic mechanisms. Mixed chimeric mice, with $50 \%$ wild-type bone marrow and 50\% conditional Dicer KO bone marrow, exhibit an impairment of FO B-cell generation and an increase in the MZ compartment only in the KO part. This confirms that the augmentation of MZ B cells in Dicer-deficient mice is not a homeostatic response but instead reflects an altered process in B-cell fate induced by the absence of miRNAs (69). Remarkably, FO B cells have a higher expression of Dicer than MZ B cells, suggesting a central role for miRNAs in this population. Indeed, among the 177 measured, 31 differentially expressed miRNAs have been highlighted in FO and MZ B cells. Among them, miR-185 was identified as central for the differentiation into the FO compartment (69). MiR-185 targets burton tyrosine kinase (BTK), which transduces signals downstream of BCR by phosphorylating Erk pathway. Consequently, by targeting BTK, miR-185 modulates BCR signals and its activation threshold. Thus, in physiological conditions, miR-185 dampens BCR signals, confirming that immature $\mathrm{B}$ cells needs strong BCR activation to differentiate into FO B cells (70). In Dicer-deficient mice, BCR signals are not diminished and so immature B cells preferentially differentiate into the MZ compartment. In addition, Dicer KO mice exhibit autoimmune features with a skewed antibody repertoire enriched in self-reactive specificities that lead to the development of autoimmune diseases (69). Concentration of IgG against dsDNA, ssDNA, and cardiolipin autoantigens are increased in Dicer KO mice, suggesting a passive biased selection of the BCR repertoire, probably due to alterations in BCR signals. More interestingly, these autoimmune features are only found in older female mice, mimicking thus the etiology of autoimmune diseases in human where older women are more susceptible to developing such pathologies (71).

\section{ROLES OF MIRNAS IN THE CONTROL OF MEMORY AND HUMORAL RESPONSES}

Memory and plasma cells are generated during the primary immune response against foreign antigens. This process is initiated when naïve FO and MZ B cells expressing surface Ig bind the antigen in secondary lymphoid organs, receive or do not receive signals from helper $\mathrm{T}$ cells, and proliferate. This proliferation produces short-lived plasmablasts and GC cells. A secondary 
diversification process occurs in the GC where B cells switch their Ig constant region from IgM to IgG, IgA, or IgE and generate somatic mutations in their variable regions. B cells expressing high affinity Ig survive and emerge from the GC reaction and differentiate into plasma cells. Recently, a number of studies have identified the involvement of miRNAs in the GC reaction and B-cell memory responses. Mice lacking miR-155 exhibit substantial immune defects with reductions in GC B cells and dampened B-cell memory responses accompanied by an alteration in the function of $\mathrm{T}$ lymphocytes and dendritic cells $(43,72)$. miR-155 deficiency in $B$ cells leads to a reduced generation of high-affinity antibodies against a T-cell-dependent antigen (19). The authors have identified the transcription factor PU.1 among targets of this miRNA. Furthermore, they have shown that $P u .1$ over-expression in B cells results in reduced numbers of IgG1-switched cells, reinforcing the evidence of this factor in B-cell maturation. In addition, the gene coding for the activation-induced cytidine deaminase (Aid gene) regulating the class-switch recombination and somatic hypermutation, has also been shown to be a miR-155 target $(20,22)$. Aid is also a target gene for miR-181b, impairing the class-switch recombination, and its expression is down-regulated upon B-cell activation, allowing efficient antibody maturation (27). Although the majority of miRNAs are down-regulated upon B-cell activation, miR-210 has been shown to be up-regulated in these circumstances (28). In models of $\mathrm{KO}$ and transgenic mice, miR-210, itself under the control of the transcription factor OCT-2, is involved in the control of immunoglobin class-switch preventing autoimmunity (28) and mice deficient in miR-210 spontaneously produce high levels of autoantibodies.

Collectively these data demonstrate that miRNAs have a key role in the differentiation of peripheral mature $B$ cells and in humoral responses. In addition, the data suggest that deregulation of miRNA expression can alter B-cell homeostasis and break tolerance by favoring the generation of autoantibodies. Regarding the significance of miRNAs in B-cell biology, we can also assume that miRNAs are involved in other essential functions of B-cells. However, to our knowledge, no miRNA has yet been described as playing a direct role in B cells functions such as antigen presentation to $\mathrm{T}$ cells, cytokine secretion or regulatory functions (73).

\section{mIRNA DYSREGULATION IN B-CELL-RELATED DISORDERS B-CELL-RELATED miRNAs IN AUTOIMMUNE DISORDERS}

B-cells are involved in autoimmune diseases due to their primary function of antibody production. That miRNA plays a role in the establishment of autoimmunity has been strongly suggested in rodents (69), but few studies have been performed specifically on human B cells. Stagakis et al. found seven miRNAs with differential expression in peripheral B cells in a small group of 5 patients with SLE, compared to three healthy controls (18). Three were underexpressed in SLE (miR-150, miR-16, miR-15a) and the four others were up-regulated (miR-155, miR-25, miR-21, miR-106b). Interestingly, miR-21, a pleiotropic miRNA described as controlling major cell functions, had also been shown to be over-expressed in splenic B cells from two mice models of SLE, the MRL/lpr and the B6.Sle123 mouse strains, suggesting it has a role in this pathology $(74,75)$. Among others, miR-15a modulation has also been described in another SLE model, B/W mice enhanced by IFN $\lambda$, with a significant correlation between miR-15a expression and autoantibody production in SLE prone-B/W mice (76). Surprisingly, miR-15a expression is essentially found in the regulatory B-cell subset under steady state and its expression progressively increases in other B-cell subsets along the course of the disease. However, in this study, miR-15a is over-expressed in splenic B cells, although it has previously been described as down-expressed in human blood B cells (18). Further investigation is required to decipher whether this discrepancy is due to differences in the origins of the analyzed B cells (peripheral blood vs. splenic B cells) or to differences between the mice model and human SLE. Even if miRNA sequences are well conserved between species, their expression profiles could be different from one species to another. For example, among 12 analyzed miRNAs which were expressed both in human and mouse, only 6 had similar expression profiles in their lymphocyte subsets (mainly CD4 ${ }^{+}$cells) (77). Using a hypothesis-driven approach, miR-30a was shown to directly target Lyn, a member of the Src family preferentially expressed in B cells (78). Gene and protein levels of Lyn are lower in SLE patients and negatively correlate with the expression of miR-30a in blood $\mathrm{CD}{ }^{+}$purified cells (78). Unlike other members of the miR30 family, only miR-30a exhibits regulatory capacity upon B-cell proliferation and antibody production in the two B-cell lines studied (Daudi and Raji). Interestingly, miR-142-3p and -5p, which are down-regulated in $\mathrm{CD} 4^{+} \mathrm{T}$ cells from SLE patients, have an indirect effect on IgG production; the over-expression of these miRNAs in SLE CD4 ${ }^{+}$T-cells induces a decrease in IgG production (79). In multiple sclerosis (MS), two studies from the same group show two sets of modulated miRNAs in isolated B cells from relapsing-remitting MS patients compared to healthy controls $(80,81)$. Despite no overlapping miRNAs, five differential miRNAs from the second study have been validated in a second set of samples and could thus be investigated to decipher B-cell deregulation in MS (miR-106b, miR-19b, miR-181a, miR-25, and miR-93) (81).

The over-expression of miR-146a has been reported in synovial tissue from patients with rheumatoid arthritis. In situ hybridization analysis reveals that $\mathrm{CD} 79 \mathrm{~A}^{+} \mathrm{B}$ cells express high amounts of miR-146a in these synovial tissues (13). Similarly, miR-146a is over-expressed in kidney biopsy and urine from patients with IgA nephropathy, although its specific expression has not been proven (15). The involvement of miR-146a in immune disorders is further suggested by the generation of transgenic mice over-expressing miR-146a with immune disorders including enlarged spleens and lymph nodes, increased frequency and numbers of $\mathrm{T}$ and $\mathrm{B}$ cells, accumulation of GC B cells, and an increase in Ig serum levels (11). MiR-146a mediates its effect by repressing the expression of Fas in B cells, a molecule essentially expressed on GCB cells and which promotes their apoptosis during GC reaction. Thus overexpression of this miRNA enhances homeostatic B-lymphocyte proliferation leading to the development of autoimmune lymphoproliferative syndrome. In concordance with these observations, higher levels of miR-146a have been found in patients suffering from rheumatoid arthritis and psoriasis (12-14). 


\section{B-CELL-RELATED miRNAs IN SOLID ORGAN TRANSPLANTATION}

An increasing number of articles dealing with miRNAs and solid organ transplantation, including kidney, liver, and lung, suggest their significant role in organ acceptance or rejection and their usefulness as biomarkers $(82,83)$. Regarding B cells, several miRNAs have been identified in biopsy or peripheral blood mononuclear cells from patients with antibody-mediated rejection (AMR) in renal transplantation (84-86). The link between these miRNAs and B cells is probable, but because B cells can exercise their function at a distance from the graft and because other factors participate in the AMR process, further investigation is required to demonstrate that these miRNAs are really involved. To our knowledge, we were the first to report miRNA dysregulation specifically in B cells after transplantation. We reported the over-expression of miR-142-3p in blood B cells from patients with operational tolerance, a specific situation where transplant patients maintain a well-functioning graft having stopped their immunosuppressive treatment (87). The over-expression of miR$142-3 p$ in the Raji B-cell line induces the modulation of genes previously described as associated with renal tolerance, suggesting that it may contribute to the maintenance of tolerance in B cells. These observations were reinforced by the observation that miR-142-3p may play a regulatory role in $\mathrm{T}$ lymphocytes by controlling leukocyte activation (79). In addition, miR-155 has been shown to contribute to resistance to Rituximab in inducing cell survival signals through AKT and myeloid cell leukemia sequence 1 (MCL1) since its inhibition resulted in a significant decrease in the survival of EBV-positive cells treated with Rituximab (24). These results indicate that the inhibition of miR-155 could be a valuable approach for treating EBV-induced PTLD.

Of course, other phenomena not directly related to B cells could occur during transplantation, including ischemia and reperfusion, cellular rejection, and recurrence of the initial disease, and miRNAs could be associated with these. In renal transplantation, miR-142-5p, shown to be present during chronic AMR, has been previously indicated as over-expressed in biopsies from patients with cellular acute rejection $(85,88)$. Similarly, miR-142$3 \mathrm{p}$, related to $\mathrm{B}$ cells in renal operational tolerance, has been found to be associated with interstitial fibrosis and tubular atrophy in urine $(87,89)$.

\section{B-CELL-RELATED miRNA USEFULNESS IN THERAPY}

Since miRNAs can be detected and measured in various body fluids, they may represent ideal non-invasive biomarkers. Among recent, numerous examples, miR-210 has been proposed as an urinary biomarker of acute rejection in renal transplantation (48), miR-142-5p to diagnose chronic AMR in renal allograft (85), and miR-155 to predict patients with CLL who fail to achieve a complete response in plasma samples collected before treatment initiation (90).

As a result, the use of miRNA inhibitors, otherwise known as antagomirs, may be promising as therapeutic tools. One particular example is the use of miRNA inhibitor against miR-122, a liver specific microRNA required by the hepatitis $\mathrm{C}$ virus (HCV) for replication. The use of this miR-122 inhibitor, "miravirsen," induced a decrease in HCV RNA levels in a dose-dependent manner in a clinical phase II study (91). Other inhibitors of miRNAs have been proposed for various diseases and it can be assumed that B-cell targeting ones will be designed in the future, for example to impair their production of antibodies. However, the targeted miRNAs generally have several functions in several different cell types and while their inhibition could provide powerful remedies, they could also have wide-reaching side-effects and caution is mandatory.

Finally, it has recently been proposed to use B cells as producers and delivers of therapeutic miRNAs in CD8 ${ }^{+} \mathrm{T}$ cells (92). After in vitro transfection of B cells with a plasmid coding for miR-155, these $\mathrm{B}$ cells delivered miR-155 in $\mathrm{CD}^{+} \mathrm{T}$ cells during antigen cross-priming only (92). The authors suggest this cellbased strategy could be used in inflammation and autoimmune diseases.

\section{CONCLUSION}

Recent studies have clearly demonstrated that miRNAs are involved in B-cell development and function. With the current interest in miRNAs, as well as the renewed emphasis on B-cell function, notably triggered by the recent discovery of regulatory B cells, it seems clear that further discoveries will be made in the near future. Ideally, theses insights would allow the use of miRNAs as disease biomarkers, but may also allow modulation of miRNA expression as master gene modulators to cure B-cell-related immune disorders.

\section{ACKNOWLEDGMENTS}

The Institute of Liver Studies (KCL) is supported by the Medical Research Council (MRC) Centre for Transplantation, King's College London, UK - MRC grant no. MR/J006742/1 and by the National Institute for Health Research (NIHR) Biomedical Research Centre at Guy's and St Thomas' NHS Foundation Trust and King's College London. The views expressed are those of the author(s) and not necessarily those of the NHS, the NIHR or the Department of Health. This work was realized in the context of the IHU-Cesti project which received French government financial support managed by the National Research Agency via the investment of the future program ANR-10-IBHU-005. The IHUCesti project is also supported by Nantes Metropole and the Pays de la Loire Region. Richard Danger was supported by the "Fondation Centaure" (RTRS; http://www.fondation-centaure.org/) which supports a French research network in transplantation.

\section{REFERENCES}

1. Stefani G, Slack FJ. Small non-coding RNAs in animal development. Nat Rev Mol Cell Biol (2008) 9:219-30. doi:10.1038/nrm2347

2. Williams AE. Functional aspects of animal microRNAs. Cell Mol Life Sci (2008) 65:545-62. doi:10.1007/s00018-007-7355-9

3. Koralov SB, Muljo SA, Galler GR, Krek A, Chakraborty T, Kanellopoulou C, et al. Dicer ablation affects antibody diversity and cell survival in the B lymphocyte lineage. Cell (2008) 132:860-74. doi:10.1016/j.cell.2008.02.020

4. Xiao C, Srinivasan L, Calado DP, Patterson HC, Zhang B, Wang J, et al. Lymphoproliferative disease and autoimmunity in mice with increased miR-17-92 expression in lymphocytes. Nat Immunol (2008) 9:405-14. doi:10.1038/ni1575

5. Nguyen T, Rich A, Dahl R. MiR-24 promotes the survival of hematopoietic cells. PLoS One (2013) 8:e55406. doi:10.1371/journal.pone.0055406 
6. Kong KY, Owens KS, Rogers JH, Mullenix J, Velu CS, Grimes HL, et al. MIR-23A microRNA cluster inhibits B-cell development. Exp Hematol (2010) 38:629.e-40.e. doi:10.1016/j.exphem.2010.04.004

7. Pekarsky Y, Santanam U, Cimmino A, Palamarchuk A, Efanov A, Maximov V, et al. Tcll expression in chronic lymphocytic leukemia is regulated by miR-29 and miR-181. Cancer Res (2006) 66:11590-3. doi:10.1158/0008-5472.CAN-063613

8. Santanam U, Zanesi N, Efanov A, Costinean S, Palamarchuk A, Hagan JP, et al. Chronic lymphocytic leukemia modeled in mouse by targeted miR-29 expression. Proc Natl Acad Sci U S A (2010) 107:12210-5. doi:10.1073/pnas. 1007186107

9. Rao DS, O'connell RM, Chaudhuri AA, Garcia-Flores Y, Geiger TL, Baltimore D. MicroRNA-34a perturbs B lymphocyte development by repressing the forkhead box transcription factor Foxp1. Immunity (2010) 33:48-59. doi:10.1016/j.immuni.2010.06.013

10. Boldin MP, Taganov KD, Rao DS, Yang L, Zhao JL, Kalwani M, et al. miR-146a is a significant brake on autoimmunity, myeloproliferation, and cancer in mice. J Exp Med (2011) 208:1189-201. doi:10.1084/jem.20101823

11. Guo Q, Zhang J, Li J, Zou L, Zhang J, Xie Z, et al. Forced miR-146a expression causes autoimmune lymphoproliferative syndrome in mice via downregulation of Fas in germinal center B cells. Blood (2013) 121:4875-83. doi:10.1182/blood-2012-08-452425

12. Sonkoly E, Wei T, Janson PC, Saaf A, Lundeberg L, Tengvall-Linder M, et al. MicroRNAs: novel regulators involved in the pathogenesis of psoriasis? PLoS One (2007) 2:e610. doi:10.1371/journal.pone.0000610

13. Nakasa T, Miyaki S, Okubo A, Hashimoto M, Nishida K, Ochi M, et al. Expression of microRNA-146 in rheumatoid arthritis synovial tissue. Arthritis Rheum (2008) 58:1284-92. doi:10.1002/art.23429

14. Stanczyk J, Pedrioli DM, Brentano F, Sanchez-Pernaute O, Kolling C, Gay RE, et al. Altered expression of MicroRNA in synovial fibroblasts and synovial tissue in rheumatoid arthritis. Arthritis Rheum (2008) 58:1001-9. doi:10.1002/art. 23386

15. Wang G, Kwan BC, Lai FM, Chow KM, Li PK, Szeto CC. Elevated levels of miR-146a and miR-155 in kidney biopsy and urine from patients with IgA nephropathy. Dis Markers (2011) 30:171-9. doi:10.3233/DMA-2011-0766

16. Cameron JE, Yin Q, Fewell C, Lacey M, McBride J, Wang X, et al. EpsteinBarr virus latent membrane protein 1 induces cellular MicroRNA miR-146a, a modulator of lymphocyte signaling pathways. J Virol (2008) 82(4):1946-58. doi:10.1128/JVI.02136-07

17. Xiao C, Calado DP, Galler G, Thai TH, Patterson HC, Wang J, et al. MiR-150 controls B cell differentiation by targeting the transcription factor c-Myb. Cell (2007) 131:146-59. doi:10.1016/j.cell.2007.07.021

18. Stagakis E, Bertsias G, Verginis P, Nakou M, Hatziapostolou M, Kritikos H, et al. Identification of novel microRNA signatures linked to human lupus disease activity and pathogenesis: miR-21 regulates aberrant $\mathrm{T}$ cell responses through regulation of PDCD4 expression. Ann Rheum Dis (2011) 70:1496-506. doi:10.1136/ard.2010.139857

19. Vigorito E, Perks KL, Abreu-Goodger C, Bunting S, Xiang Z, Kohlhaas S, et al. microRNA-155 regulates the generation of immunoglobulin class-switched plasma cells. Immunity (2007) 27:847-59. doi:10.1016/j.immuni.2007.10.009

20. Teng G, Hakimpour P, Landgraf P, Rice A, Tuschl T, Casellas R, et al. MicroRNA155 is a negative regulator of activation-induced cytidine deaminase. Immunity (2008) 28:621-9. doi:10.1016/j.immuni.2008.03.015

21. Pedersen IM, Otero D, Kao E, Miletic AV, Hother C, Ralfkiaer E, et al. OncomiR-155 targets SHIP1 to promote TNFalpha-dependent growth of B cell lymphomas. EMBO Mol Med (2009) 1:288-95. doi:10.1002/emmm.200900028

22. Dorsett Y, Mcbride KM, Jankovic M, Gazumyan A, Thai TH, Robbiani DF, et al. MicroRNA-155 suppresses activation-induced cytidine deaminase-mediated Myc-Igh translocation. Immunity (2008) 28:630-8. doi:10.1016/j.immuni.2008. 04.002

23. Yin Q, Wang X, Fewell C, Cameron J, Zhu H, Baddoo M, et al. MicroRNA miR155 inhibits bone morphogenetic protein (BMP) signaling and BMP-mediated Epstein-Barr virus reactivation. J Viro (2010) 84(13):6318-27. doi:10.1128/JVI. 00635-10

24. Kim JH, Kim WS, Park C. Epstein-Barr virus latent membrane protein-1 protects B-cell lymphoma from rituximab-induced apoptosis through miR-155mediated Akt activation and up-regulation of Mcl-1. Leuk Lymphoma (2012) 53:1586-91. doi:10.3109/10428194.2012.659736
25. Lwin T, Lin J, Choi YS, Zhang X, Moscinski LC, Wright KL, et al. Follicular dendritic cell-dependent drug resistance of non-Hodgkin lymphoma involves cell adhesion-mediated Bim down-regulation through induction of microRNA181a. Blood (2010) 116:5228-36. doi:10.1182/blood-2010-03-275925

26. Chen CZ, Li L, Lodish HF, Bartel DP. MicroRNAs modulate hematopoietic lineage differentiation. Science (2004) 303:83-6. doi:10.1126/science.1091903

27. de Yebenes VG, Belver L, Pisano DG, Gonzalez S, Villasante A, Croce C, et al. miR-181b negatively regulates activation-induced cytidine deaminase in B cells. J Exp Med (2008) 205:2199-206. doi:10.1084/jem.20080579

28. Mok Y, Schwierzeck V, Thomas DC, Vigorito E, Rayner TF, Jarvis LB, et al. MiR210 is induced by Oct-2, regulates B cells, and inhibits autoantibody production. J Immunol (2013) 191(6):3037-48. doi:10.4049/jimmunol.1301289

29. Knoll M, Simmons S, Bouquet C, Grun JR, Melchers F. miR-221 redirects precursor B cells to the BM and regulates their residence. Eur J Immunol (2013) 43(9):2497-506. doi:10.1002/eji.201343367

30. Lee RC, Feinbaum RL, Ambros V. The C. elegans heterochronic gene lin-4 encodes small RNAs with antisense complementarity to lin-14. Cell (1993) 75:843-54. doi:10.1016/0092-8674(93)90529-Y

31. Wightman B, Ha I, Ruvkun G. Posttranscriptional regulation of the heterochronic gene lin-14 by lin-4 mediates temporal pattern formation in C. elegans. Cell (1993) 75:855-62. doi:10.1016/0092-8674(93)90530-4

32. Kozomara A, Griffiths-Jones S. miRBase: integrating microRNA annotation and deep-sequencing data. Nucleic Acids Res (2011) 39:D152-7. doi:10.1093/nar/ gkq1027

33. Kim VN, Han J, Siomi MC. Biogenesis of small RNAs in animals. Nat Rev Mol Cell Biol (2009) 10:126-39. doi:10.1038/nrm2632

34. Lee Y, Kim M, Han J, Yeom KH, Lee S, Baek SH, et al. MicroRNA genes are transcribed by RNA polymerase II. EMBO J (2004) 23:4051-60. doi:10.1038/sj. emboj.7600385

35. Bartel DP. MicroRNAs: genomics, biogenesis, mechanism, and function. Cell (2004) 116:281-97. doi:10.1016/S0092-8674(04)00045-5

36. Lewis BP, Shih IH, Jones-Rhoades MW, Bartel DP, Burge CB. Prediction of mammalian microRNA targets. Cell (2003) 115:787-98. doi:10.1016/S0092-8674(03) 01018-3

37. Baek D, Villén J, Shin C, Camargo FD, Gygi SP, Bartel DP. The impact of microRNAs on protein output. Nature (2008) 455:64-71. doi:10.1038/nature07242

38. Guo H, Ingolia NT, Weissman JS, Bartel DP. Mammalian microRNAs predominantly act to decrease target mRNA levels. Nature (2010) 466:835-40. doi:10.1038/nature09267

39. Maziere P, Enright AJ. Prediction of microRNA targets. Drug Discov Today (2007) 12:452-8. doi:10.1016/j.drudis.2007.04.002

40. Mathonnet G, Fabian MR, Svitkin YV, Parsyan A, Huck L, Murata T, et al. MicroRNA inhibition of translation initiation in vitro by targeting the cap-binding complex eIF4F. Science (2007) 317:1764-7. doi:10.1126/science. 1146067

41. Bazzini AA, Lee MT, Giraldez AJ. Ribosome profiling shows that miR-430 reduces translation before causing mRNA decay in zebrafish. Science (2012) 336:233-7. doi:10.1126/science.1215704

42. Djuranovic S, Nahvi A, Green R. miRNA-mediated gene silencing by translational repression followed by mRNA deadenylation and decay. Science (2012) 336:237-40. doi:10.1126/science.1215691

43. Rodriguez A, Vigorito E, Clare S, Warren MV, Couttet P, Soond DR, et al. Requirement of bic/microRNA-155 for normal immune function. Science (2007) 316:608-11. doi:10.1126/science.1139253

44. Banerjee A, Schambach F, Dejong CS, Hammond SM, Reiner SL. Micro-RNA155 inhibits IFN-gamma signaling in CD4+ T cells. Eur J Immunol (2010) 40:225-31. doi:10.1002/eji.200939381

45. Schott J, Stoecklin G. Networks controlling mRNA decay in the immune system. Wiley Interdiscip Rev RNA (2010) 1:432-56. doi:10.1002/wrna.13

46. Allantaz F, Cheng DT, Bergauer T, Ravindran P, Rossier MF, Ebeling M, et al. Expression profiling of human immune cell subsets identifies miRNA-mRNA regulatory relationships correlated with cell type specific expression. PLoS One (2012) 7:e29979. doi:10.1371/journal.pone.0029979

47. Weber JA, Baxter DH, Zhang S, Huang DY, Huang KH, Lee MJ, et al. The microRNA spectrum in 12 body fluids. Clin Chem (2010) 56:1733-41. doi:10. 1373/clinchem.2010.147405

48. Lorenzen JM, Volkmann I, Fiedler J, Schmidt M, Scheffner I, Haller H, et al. Urinary miR-210 as a mediator of acute T-cell mediated rejection in renal allograft 
recipients. Am J Transplant (2011) 11:2221-7. doi:10.1111/j.1600-6143.2011. 03679.x

49. Vasudevan S, Tong Y, Steitz JA. Switching from repression to activation: microRNAs can up-regulate translation. Science (2007) 318:1931-4. doi:10.1126/ science. 1149460

50. Place RF, Li LC, Pookot D, Noonan EJ, Dahiya R. MicroRNA-373 induces expression of genes with complementary promoter sequences. Proc Natl Acad Sci U S A (2008) 105:1608-13. doi:10.1073/pnas.0707594105

51. Lytle JR, Yario TA, Steitz JA. Target mRNAs are repressed as efficiently by microRNA-binding sites in the 5' UTR as in the 3' UTR. Proc Natl Acad Sci U S A (2007) 104:9667-72. doi:10.1073/pnas.0703820104

52. Cesana M, Cacchiarelli D, Legnini I, Santini T, Sthandier O, Chinappi M, et al. A long noncoding RNA controls muscle differentiation by functioning as a competing endogenous RNA. Cell (2011) 147:358-69. doi:10.1016/j.cell.2011.09.028

53. O'Carroll D, Mecklenbrauker I, Das PP, Santana A, Koenig U, Enright AJ, et al. A slicer-independent role for argonaute 2 in hematopoiesis and the microRNA pathway. Genes Dev (2007) 21:1999-2004. doi:10.1101/gad.1565607

54. Xu S, Guo K, Zeng Q, Huo J, Lam KP. The RNase III enzyme Dicer is essential for germinal center B-cell formation. Blood (2012) 119:767-76. doi:10.1182/blood2011-05-355412

55. Spierings DC, Mcgoldrick D, Hamilton-Easton AM, Neale G, Murchison EP, Hannon GJ, et al. Ordered progression of stage-specific miRNA profiles in the mouse B2 B-cell lineage. Blood (2011) 117:5340-9. doi:10.1182/blood-201010-316034

56. Chang TC, Yu D, Lee YS, Wentzel EA, Arking DE, West KM, et al. Widespread microRNA repression by Myc contributes to tumorigenesis. Nat Genet (2008) 40:43-50. doi:10.1038/ng.2007.30

57. Peveling-Oberhag J, Crisman G, Schmidt A, Doring C, Lucioni M, Arcaini L, et al. Dysregulation of global microRNA expression in splenic marginal zone lymphoma and influence of chronic hepatitis C virus infection. Leukemia (2012) 26:1654-62. doi:10.1038/leu.2012.29

58. Di Lisio L, Martinez N, Montes-Moreno S, Piris-Villaespesa M, Sanchez-Beato $\mathrm{M}$, Piris MA. The role of miRNAs in the pathogenesis and diagnosis of B-cell lymphomas. Blood (2012) 120:1782-90. doi:10.1182/blood-2012-05-402784

59. Liston A, Papadopoulou AS, Danso-Abeam D, Dooley J. MicroRNA-29 in the adaptive immune system: setting the threshold. Cell Mol Life Sci (2012) 69:3533-41. doi:10.1007/s00018-012-1124-0

60. Landgraf P, Rusu M, Sheridan R, Sewer A, Iovino N, Aravin A, et al. A mammalian microRNA expression atlas based on small RNA library sequencing. Cell (2007) 129:1401-14. doi:10.1016/j.cell.2007.04.040

61. Liang Y, Ridzon D, Wong L, Chen C. Characterization of microRNA expression profiles in normal human tissues. BMC Genomics (2007) 8:166. doi:10.1186/ 1471-2164-8-166

62. Ramkissoon SH, Mainwaring LA, Ogasawara Y, Keyvanfar K, Mccoy JP Jr, Sloand $\mathrm{EM}$, et al. Hematopoietic-specific microRNA expression in human cells. Leuk Res (2006) 30:643-7. doi:10.1016/j.leukres.2005.09.001

63. Merkerova M, Belickova M, Bruchova H. Differential expression of microRNAs in hematopoietic cell lineages. Eur J Haematol (2008) 81:304-10. doi:10.1111/j. 1600-0609.2008.01111.x

64. Basso K, Sumazin P, Morozov P, Schneider C, Maute RL, Kitagawa Y, et al. Identification of the human mature B cell miRNome. Immunity (2009) 30:744-52. doi:10.1016/j.immuni.2009.03.017

65. Malumbres R, Sarosiek KA, Cubedo E, Ruiz JW, Jiang X, Gascoyne RD, et al. Differentiation stage-specific expression of microRNAs in B lymphocytes and diffuse large B-cell lymphomas. Blood (2009) 113:3754-64. doi:10.1182/blood2008-10-184077

66. Meffre E, Casellas R, Nussenzweig MC. Antibody regulation of B cell development. Nat Immunol (2000) 1:379-85. doi:10.1038/80816

67. Meffre E, Wardemann H. B-cell tolerance checkpoints in health and autoimmunity. Curr Opin Immunol (2008) 20:632-8. doi:10.1016/j.coi.2008.09.001

68. Carsetti R, Rosado MM, Wardmann H. Peripheral development of B cells in mouse and man. Immunol Rev (2004) 197:179-91. doi:10.1111/j.0105-2896. 2004.0109.x

69. Belver L, De Yebenes VG, Ramiro AR. MicroRNAs prevent the generation of autoreactive antibodies. Immunity (2010) 33:713-22. doi:10.1016/j.immuni. 2010.11.010

70. Pillai S, Cariappa A. The follicular versus marginal zone B lymphocyte cell fate decision. Nat Rev Immunol (2009) 9:767-77. doi:10.1038/nri2656
71. Whitacre CC. Sex differences in autoimmune disease. Nat Immunol (2001) 2:777-80. doi:10.1038/ni0901-777

72. Thai TH, Calado DP, Casola S, Ansel KM, Xiao C, Xue Y, et al. Regulation of the germinal center response by microRNA-155. Science (2007) 316:604-8. doi:10.1126/science.1141229

73. Lund FE, Randall TD. Effector and regulatory B cells: modulators of CD4+ T cell immunity. Nat Rev Immunol (2010) 10:236-47. doi:10.1038/nri2729

74. Pan W, Zhu S, Yuan M, Cui H, Wang L, Luo X, et al. MicroRNA-21 and microRNA-148a contribute to DNA hypomethylation in lupus CD4+ T cells by directly and indirectly targeting DNA methyltransferase 1. J Immunol (2010) 184:6773-81. doi:10.4049/jimmunol.0904060

75. Garchow BG, Bartulos Encinas O, Leung YT, Tsao PY, Eisenberg RA, Caricchio $\mathrm{R}$, et al. Silencing of microRNA-21 in vivo ameliorates autoimmune splenomegaly in lupus mice. EMBO Mol Med (2011) 3:605-15. doi:10.1002/ emmm.201100171

76. Yuan Y, Kasar S, Underbayev C, Vollenweider D, Salerno E, Kotenko SV, et al. Role of microRNA-15a in autoantibody production in interferon-augmented murine model of lupus. Mol Immunol (2012) 52:61-70. doi:10.1016/j.molimm. 2012.04.007

77. Rossi RL, Rossetti G, Wenandy L, Curti S, Ripamonti A, Bonnal RJ, et al. Distinct microRNA signatures in human lymphocyte subsets and enforcement of the naive state in CD4+ T cells by the microRNA miR-125b. Nat Immunol (2011) 12:796-803. doi:10.1038/ni.2057

78. Liu Y, Dong J, Mu R, Gao Y, Tan X, Li Y, et al. MicroRNA-30a promotes B cell hyperactivity in patients with systemic lupus erythematosus by direct interaction with Lyn. Arthritis Rheum (2013) 65:1603-11. doi:10.1002/art.37912

79. Ding S, Liang Y, Zhao M, Liang G, Long H, Zhao S, et al. Decreased microRNA142-3p/5p expression causes CD4+ T cell activation and B cell hyperstimulation in systemic lupus erythematosus. Arthritis Rheum (2012) 64:2953-63. doi:10.1002/art.34505

80. Lindberg RL, Hoffmann F, Mehling M, Kuhle J, Kappos L. Altered expression of miR-17-5p in CD4+ lymphocytes of relapsing-remitting multiple sclerosis patients. Eur J Immunol (2010) 40:888-98. doi:10.1002/eji.200940032

81. Sievers C, Meira M, Hoffmann F, Fontoura P, Kappos L, Lindberg RL. Altered microRNA expression in B lymphocytes in multiple sclerosis: towards a better understanding of treatment effects. Clin Immunol (2012) 144:70-9. doi:10. 1016/j.clim.2012.04.002

82. Anglicheau D, Muthukumar T, Suthanthiran M. MicroRNAs: small RNAs with big effects. Transplantation (2010) 90:105-12. doi:10.1097/TP. 0b013e3181e913c2

83. Sarma NJ, Tiriveedhi V, Ramachandran S, Crippin J, Chapman W, Mohanakumar T. Modulation of immune responses following solid organ transplantation by microRNA. Exp Mol Pathol (2012) 93:378-85. doi:10.1016/j. yexmp.2012.09.020

84. Ben-Dov IZ, Muthukumar T, Morozov P, Mueller FB, Tuschl T, Suthanthiran M. MicroRNA sequence profiles of human kidney allografts with or without tubulointerstitial fibrosis. Transplantation (2012) 94:1086-94. doi:10.1097/TP. 0b013e3182751efd

85. Danger R, Paul C, Giral M, Lavault A, Foucher Y, Degauque N, et al. Expression of miR-142-5p in peripheral blood mononuclear cells from renal transplant patients with chronic antibody-mediated rejection. PLoS One (2013) 8(4):e60702. doi:10.1371/journal.pone.0060702

86. Wilflingseder J, Regele H, Perco P, Kainz A, Soleiman A, Muhlbacher F, et al. miRNA profiling discriminates types of rejection and injury in human renal allografts. Transplantation (2013) 95:835-41. doi:10.1097/TP.0b013e318280b385

87. Danger R, Pallier A, Giral M, Martinez-Llordella M, Lozano JJ, Degauque N, et al. Upregulation of miR-142-3p in peripheral blood mononuclear cells of operationally tolerant patients with a renal transplant. J Am Soc Nephrol (2012) 23:597-606. doi:10.1681/ASN.2011060543

88. Anglicheau D, Sharma VK, Ding R, Hummel A, Snopkowski C, Dadhania D, et al. MicroRNA expression profiles predictive of human renal allograft status. Proc Natl Acad Sci U S A (2009) 106:5330-5. doi:10.1073/pnas.0813121106

89. Scian MJ, Maluf DG, David KG, Archer KJ, Suh JL, Wolen AR, et al. MicroRNA profiles in allograft tissues and paired urines associate with chronic allograft dysfunction with IF/TA. Am J Transplant (2011) 11:2110-22. doi:10.1111/j.16006143.2011.03666.x

90. Ferrajoli A, Shanafelt TD, Ivan C, Shimizu M, Rabe KG, Nouraee N, et al. Prognostic value of miR-155 in individuals with monoclonal B-cell lymphocytosis 
and patients with B chronic lymphocytic leukemia. Blood (2013) 122:1891-9. doi:10.1182/blood-2013-01-478222

91. Janssen HL, Reesink HW, Lawitz EJ, Zeuzem S, Rodriguez-Torres M, Patel K, et al. Treatment of HCV infection by targeting microRNA. N Engl J Med (2013) 368:1685-94. doi:10.1056/NEJMoa1209026

92. Almanza G, Anufreichik V, Rodvold JJ, Chiu KT, Delaney A, Akers JC, et al. Synthesis and delivery of short, noncoding RNA by B lymphocytes. Proc Natl Acad Sci U S A (2013) 110:20182-7. doi:10.1073/pnas.1311145110

Conflict of Interest Statement: The authors declare that the research was conducted in the absence of any commercial or financial relationships that could be construed as a potential conflict of interest.
Received: 01 October 2013; accepted: 24 February 2014; published online: 11 March 2014.

Citation: Danger R, Braza F, Giral M, Soulillou J-P and Brouard S (2014) MicroRNAs, major players in B cells homeostasis and function. Front. Immunol. 5:98. doi: 10.3389/fimmu.2014.00098

This article was submitted to Alloimmunity and Transplantation, a section of the journal Frontiers in Immunology.

Copyright $\odot 2014$ Danger, Braza, Giral, Soulillou and Brouard. This is an open-access article distributed under the terms of the Creative Commons Attribution License (CC $B Y)$. The use, distribution or reproduction in other forums is permitted, provided the original author(s) or licensor are credited and that the original publication in this journal is cited, in accordance with accepted academic practice. No use, distribution or reproduction is permitted which does not comply with these terms. 